\title{
LONG-TERM FORAGE PRODUCTION OF NORTH AMERICAN SHORTGRASS STEPPE ${ }^{1}$
}

\author{
W. K. LAUENROTH \\ Department of Range Science and Natural Resource Ecology Laboratory, \\ Colorado State University, Fort Collins, Colorado 80523 USA \\ O. E. SALA \\ Department of Ecology, Faculty of Agronomy, University of Buenos Aires, \\ Avenue San Martín 4453, Buenos Aires 1417, Argentina
}

\begin{abstract}
We evaluated the relationship between annual forage production and annual and seasonal precipitation and temperature at a shortgrass steppe site in north-central Colorado using a long-term data set $(52 \mathrm{yr})$. We also constructed a relationship between forage production and aboveground net primary production (ANPP). Precipitation fluctuated randomly, but temperature had clear warming and cooling trends including a 17yr warming trend from 1974 to 1990.

Forage production was significantly related to both annual and seasonal precipitation but not temperature. Precipitation events between 15 and $30 \mathrm{~mm}$ accounted for most of the variability in production because they accounted for most of the variability in precipitation and because they wetted the soil layers that have the largest effect on production. Forage production amplified variability in annual precipitation.

Production showed time lags of several years in responding to increases in precipitation. Change in vegetation structure has a characteristic response time, which contrains production responses in wet years. Constraint caused by vegetation structure is the reason why regional ANPP-precipitation models have a steeper slope than long-term models and point out a weakness of exchanging space for time in predicting production patterns.
\end{abstract}

Key words: aboveground net primary production; forage production; population-ecosystem interactions; shortgrass steppe; spatial variability; temporal variability; water use efficiency.

\section{INTRODUCTION}

The relationship between forage production and precipitation in semiarid regions has been widely used to explain the variability in production at individual sites through time (e.g., Smoliak 1986), and spatially at the regional (e.g., Sala et al. 1988) and the global scales (e.g., Lauenroth 1979). Because of the fundamental nature of the relationship between water availability and plant production (Noy-Meir 1973), rain use efficiency (annual aboveground net primary production [ANPP] divided by annual rainfall) has been proposed as a unifying concept in arid-land ecology (Le Houérou 1984).

The reason precipitation has such large explanatory power for net primary production in arid and semiarid regions is because it is both low and variable (Bailey 1979). For example, in the shortgrass region of the Great Plains of North America there are $<60 \mathrm{~d}$ each year with detectable precipitation $(>2 \mathrm{~mm})$ and $<20$ $\mathrm{d}$ with $>6 \mathrm{~mm}$ of precipitation (Lauenroth and Milchunas 1991). Thus, the normal condition of the soil in semiarid regions is dry. This dry background condition is interrupted by infrequent wet periods. Sala et al. (1992) analyzed $33 \mathrm{yr}$ of climatic data for the Central

\footnotetext{
'Manuscript received 27 August 1991; revised and ac-
} cepted 23 December 1991.
Plains Experimental Range (CPER) in north-central Colorado and found that annual precipitation was almost twice as variable $(\mathrm{CV}=31 \%)$ as potential evapotranspiration $(\mathrm{CV}=18 \%)$. Under such conditions it is not surprising that statistical relationships between precipitation and ANPP are often reported (Rutherford 1980, Le Houérou 1984).

The objectives of this study were: (1) to evaluate the utility of the relationship between precipitation and net primary production to explain interannual variability in forage production, (2) to assess the major sources of interannual variability in forage production, and (3) to compare our long-term site-specific relationship between precipitation and production with a similar regional relationship. This work focuses on the CPER in the northern portion of the North American shortgrass steppe (Lauenroth and Milchunas 1991). We report on a long-term data set collected from 1939 to 1990.

\section{METHODS}

The CPER is located in north-central Colorado, North America, in the precipitation shadow of the Rocky Mountains, $\approx 40 \mathrm{~km}$ south of Cheyenne, Wyoming $\left(40^{\circ} 49^{\prime} \mathrm{N}, 104^{\circ} 46^{\prime} \mathrm{W}\right)$. Annual precipitation was $321 \pm 98 \mathrm{~mm}$ (mean $\pm 1 \mathrm{SD}$ ) over the $52 \mathrm{yr}$ from 1939 to 1990 (Table 1). Annual temperature averaged 8.6 
TABLE 1. Annual forage production, aboveground net primary production (ANPP), precipitation, and air temperature data for the Central Plains Experimental Range in north-central Colorado for 1939-1990.

\begin{tabular}{|c|c|c|c|c|c|c|c|c|c|c|c|}
\hline \multirow[b]{3}{*}{ Year } & \multicolumn{4}{|c|}{ Production $\left(\mathrm{g} / \mathrm{m}^{2}\right)$} & \multicolumn{7}{|c|}{ Precipitation $(\mathrm{mm})$} \\
\hline & \multicolumn{3}{|c|}{ Forage air-dry mass } & \multirow{2}{*}{$\begin{array}{l}\mathrm{ANPP}_{\mathrm{FE}} * \\
\text { (oven-dry } \\
\text { mass) }\end{array}$} & \multirow{2}{*}{$\begin{array}{c}\mathrm{ANPP}_{\mathrm{OD}} \dagger \\
\text { (oven-dry } \\
\text { mass) }\end{array}$} & \multicolumn{4}{|c|}{ Event size class } & \multirow[b]{2}{*}{ Total } & \multirow{2}{*}{$\begin{array}{c}\text { Temp } \\
\left({ }^{\circ} \mathrm{C}\right)\end{array}$} \\
\hline & Mean & SD & No. est & & & $<5$ & $5-15$ & $15-30$ & $>30$ & & \\
\hline 1939 & 50 & 12.1 & 11 & & 84 & & & & & 117 & 9.30 \\
\hline 1940 & & & 0 & & & 74 & 76 & 106 & 83 & 339 & 8.85 \\
\hline 1941 & 74 & 11.3 & 10 & & 102 & 6 & 0 & 0 & 0 & 325 & 8.43 \\
\hline 1942 & 123 & 33.3 & 7 & & 139 & 0 & 0 & 0 & 0 & 371 & 8.07 \\
\hline 1943 & 123 & 32.6 & 13 & & 140 & 80 & 159 & 137 & 115 & 490 & 8.80 \\
\hline 1944 & 75 & 24.2 & 7 & & 103 & 48 & 64 & 55 & 38 & 205 & 8.29 \\
\hline 1945 & 66 & 19.5 & 7 & & 96 & 56 & 133 & 98 & 0 & 288 & 8.00 \\
\hline 1946 & 67 & 15.2 & 9 & & 97 & 42 & 148 & 106 & 0 & 296 & 8.77 \\
\hline 1947 & 96 & 25.9 & 9 & & 119 & 67 & 117 & 84 & 70 & 338 & 8.26 \\
\hline 1948 & 50 & 14.5 & 10 & & 84 & 100 & 93 & 0 & 0 & 193 & 8.42 \\
\hline 1949 & 82 & 13.4 & 8 & & 109 & 95 & 169 & 76 & 0 & 341 & 8.56 \\
\hline 1950 & 54 & 20.7 & 18 & & 87 & 77 & 163 & 0 & 59 & 299 & 8.63 \\
\hline 1951 & 70 & 16.9 & 13 & & 99 & 80 & 126 & 89 & 35 & 330 & 7.74 \\
\hline 1952 & 95 & 24.8 & 5 & & 118 & 61 & 130 & 162 & 0 & 353 & 8.82 \\
\hline 1953 & 73 & 13.6 & 8 & & 102 & 56 & 88 & 103 & 54 & 301 & 9.38 \\
\hline 1954 & 22 & 4.3 & 6 & & 62 & 62 & 45 & 15 & 0 & 122 & 9.92 \\
\hline 1955 & 32 & 4.8 & 4 & & 70 & 89 & 74 & 133 & 31 & 328 & 8.21 \\
\hline 1956 & 50 & 13.0 & 4 & & 84 & 40 & 117 & 15 & 72 & 244 & 8.94 \\
\hline 1957 & 64 & 23.7 & 19 & & 94 & 85 & 182 & 77 & 71 & 415 & 8.29 \\
\hline 1958 & 77 & 20.7 & 19 & & 104 & 97 & 155 & 79 & 0 & 331 & 8.71 \\
\hline 1959 & 83 & 13.5 & 10 & & 109 & 68 & 146 & 56 & 37 & 307 & 8.40 \\
\hline 1960 & 57 & 8.1 & 14 & & 89 & 66 & 109 & 0 & 0 & 175 & 8.44 \\
\hline 1961 & 76 & 16.5 & 10 & & 104 & 81 & 152 & 136 & 36 & 404 & 8.20 \\
\hline 1962 & 81 & 16.3 & 10 & & 107 & 59 & 134 & 165 & 41 & 399 & 8.20 \\
\hline 1963 & 80 & 12.3 & 6 & & 107 & 59 & 86 & 155 & 38 & 338 & 8.50 \\
\hline 1964 & 25 & 4.4 & 6 & & 65 & 43 & 65 & 0 & 0 & 107 & 7.64 \\
\hline 1965 & 48 & 12.2 & 6 & & 82 & 51 & 193 & 83 & 44 & 371 & 7.63 \\
\hline 1966 & 49 & 11.9 & 6 & & 83 & 52 & 120 & 36 & 85 & 292 & 7.77 \\
\hline 1967 & 90 & 12.4 & 3 & & 115 & 70 & 174 & 177 & 167 & 588 & 7.62 \\
\hline 1968 & 77 & 26.0 & 6 & & 105 & 61 & 161 & 76 & 36 & 333 & 7.69 \\
\hline 1969 & 86 & 25.1 & 5 & & 112 & 5 & 167 & 139 & 35 & 417 & 7.89 \\
\hline 1970 & 72 & 18.7 & 6 & 115 & 101 & 70 & 101 & 71 & 0 & 242 & 8.02 \\
\hline 1971 & 73 & 8.4 & 6 & 74 & 102 & 56 & 92 & 114 & 0 & 262 & 8.16 \\
\hline 1972 & 24 & 4.4 & 7 & 85 & 64 & 72 & 181 & 55 & 67 & 374 & 8.32 \\
\hline 1973 & 68 & 14.8 & 16 & 64 & 98 & 68 & 120 & 53 & 34 & 275 & 8.36 \\
\hline 1974 & 22 & 5.7 & 13 & 55 & 63 & 43 & 91 & 64 & 70 & 268 & 9.30 \\
\hline 1975 & 63 & 20.7 & 31 & 55 & 94 & 75 & 73 & 142 & 34 & 324 & 8.88 \\
\hline 1976 & 44 & 12.0 & 28 & & 80 & 83 & 135 & 42 & 0 & 261 & 9.42 \\
\hline 1977 & 27 & 9.1 & 35 & & 67 & 57 & 108 & 83 & 0 & 248 & 9.92 \\
\hline 1978 & 37 & 16.2 & 30 & & 74 & 78 & 46 & 126 & 42 & 292 & 9.08 \\
\hline 1979 & 88 & 28.6 & 22 & & 113 & 90 & 184 & 184 & 36 & 494 & 8.94 \\
\hline 1980 & & & 0 & & & 62 & 138 & 116 & 45 & 360 & 9.60 \\
\hline 1981 & 128 & 50.4 & 16 & & 143 & 77 & 122 & 162 & 36 & 397 & 10.09 \\
\hline 1982 & 117 & 17.7 & 12 & & 135 & 74 & 106 & 139 & 155 & 475 & 9.17 \\
\hline 1983 & 91 & 29.5 & 16 & 164 & 115 & 61 & 127 & 167 & 73 & 428 & 9.02 \\
\hline 1984 & 103 & 37.4 & 8 & 108 & 124 & 85 & 152 & 100 & 70 & 407 & 9.81 \\
\hline 1985 & 84 & 10.7 & 8 & 128 & 110 & 119 & 128 & 74 & 0 & 321 & 9.07 \\
\hline 1986 & 55 & 5.1 & 3 & 119 & 88 & 108 & 157 & 0 & 0 & 265 & 10.92 \\
\hline 1987 & 63 & 4.8 & 8 & 62 & 94 & 107 & 167 & 57 & 0 & 332 & 10.52 \\
\hline 1988 & 57 & 6.8 & 8 & 90 & 90 & 76 & 80 & 92 & 86 & 335 & 10.23 \\
\hline 1989 & 55 & 5.7 & 6 & 82 & 87 & 72 & 109 & 75 & 44 & 300 & 9.93 \\
\hline 1990 & 58 & 4.7 & 6 & 110 & 90 & 96 & 158 & 104 & 0 & 357 & 10.21 \\
\hline Mean & 66 & & 11 & 94 & 97 & 54 & 119 & 99 & 44 & 321 & 8.6 \\
\hline $\mathrm{SE}$ & 29 & & 8 & 32 & 21 & 19 & 43 & 58 & 39 & 98 & 0.6 \\
\hline CV (\%) & 44 & & & 34 & 22 & 29 & 36 & 59 & 88 & 31 & 7 \\
\hline
\end{tabular}

* Field estimates of ANPP from the Central Plains Experimental Range.

$\dagger$ Eq. $1\left[\mathrm{ANPP}_{\mathrm{OD}}=46+0.76\right.$ (Forage Production) $]$ converts from air-dry forage production to oven-dry ANPP.

$\pm 0.6^{\circ} \mathrm{C}$ over the same time period (Table 1$)$ (Kittel 1990). The climate of the CPER is typical of midcontinental semiarid sites in the temperate zone except for the large influence of the Rocky Mountains $60 \mathrm{~km}$ to the west. Maxima in precipitation and temperature occur in June, July, and August, and minima occur in December, January, and February.

The vegetation is representative of the northern portion of the shortgrass steppe (Lauenroth and Milchunas 1991). Most locations at the CPER, regardless of past 
grazing history, are dominated by the perennial bunchgrass Bouteloua gracilis H.B.K. Lag ex Griffiths, which accounts for $\approx 90 \%$ of both basal cover and forage production (Milchunas et al. 1989). Associated species include Buchloë dactyloides (Nutt.) Engelm, Opuntia polyacantha Haw, Sphaeralcea coccinea (Pursh) Rydb, and Carex eleocharis Bailey. Nomenclature follows the Great Plains Flora Association (1986).

Forage production was estimated annually from 1939 to 1990 (except 1940 and 1980), although the same pastures were not sampled every year (Table 1). Because of the importance of $B$. gracilis at the CPER, most locations are similar in species composition. The standard deviations of forage production (Table 1) provide an indication of the variability among locations sampled. Samples were collected by harvesting live and attached-dead biomass of grasses, sedges, and forbs from $0.19-\mathrm{m}^{2}\left(2 \mathrm{ft}^{2}\right)$ quadrats at the end of the growing season. $O$. polyacantha was not harvested. This method has been shown to provide good estimates of aboveground net primary production (ANPP) for ecosystems such as the shortgrass steppe in which the species that account for the majority of production have similar phenologies (Lauenroth et al. 1986). An exception to this procedure occurred in the data for the years 19691972, in which masses were visually estimated but not harvested. The average number of locations sampled was 11 with a range of 3 in 1967 to 35 in 1977; no sampling was done in 1940 or 1980 (Table 1). The data presented here represent an average over the locations sampled each year. All masses are expressed on an airdry basis.

While the lack of identical sampling locations and number of locations from year to year limits the utility of the data set for some purposes, it nevertheless is valuable for an analysis of the relationship between precipitation and forage production. The reason for this is that such relationships have been shown to be sufficiently robust to be detectable even in variable data sets (Lauenroth 1979, Le Houérou 1984, Le Houérou et al. 1988). Furthermore, these data are important because very few similar data sets exist for temperate grasslands. The most important assumption for this analysis is that the estimates of forage production (airdry basis) for each year are proportional to ANPP (ovendry basis). We tested this assumption by evaluating the relationship between estimates of average forage production and estimates of ANPP.

Forage production was significantly $(F=4.66$; $\mathrm{df}=$ 1,$12 ; P=.05 ; r^{2}=0.28$ ) and positively related to ANPP by the equation:

$$
\text { ANPP }=46+0.76 \text { (Forage Production) } .
$$

This relationship was established using $14 \mathrm{yr}$ in which estimates of both ANPP and forage production were available (Table 1). Results for both forage production and ANPP are presented (Table 1).

\section{RESULTS}

The climate at the CPER is representative of sites in semiarid regions with relatively high variability in precipitation from year to year $(\mathrm{CV}=31 \%)$ and relatively low variability in temperature $(\mathrm{CV}=7 \%)$ (Table 1; Fig. 1A, B). Twenty-three of the 52 observations of annual precipitation were below the mean with no more than three of the low values occurring in consecutive years (Fig. 1B). By contrast, every year from 1959 to 1973 had an annual temperature below the mean (Fig. 1A). Annual temperature has been increasing since 1967 , and each of the years from 1974 to 1990 had temperatures above the mean. Results from a runs test indicated that the temperature deviations were not random but that the precipitation deviations were random (Draper and Smith 1966). Maximum temperature deviations were $\leq 2.5^{\circ} \mathrm{C}$ and positive; maximum precipitation deviations were $>200 \mathrm{~mm}$ and were both positive and negative.

Forage production was even more variable than precipitation (Table 1, Fig. 1C). Average forage production was $66 \mathrm{~g} / \mathrm{m}^{2}\left(\mathrm{ANPP}=97 \mathrm{~g} / \mathrm{m}^{2}\right)$ with a $\mathrm{CV}$ of $44 \%$. Twenty-four of the observations were below the mean and 27 were at or above the mean. The data clearly indicated that the interannual variability in forage production was as much a result of departures above the long-term average as below. The longest runs in deviations were positive and occurred between 19671971 and 1981-1985.

Forage production following years with very low precipitation showed a clear lag in recovery (Fig. 1). For example, precipitation in 1954 was $200 \mathrm{~mm}$ below the long-term mean, and forage production was $40 \mathrm{~g} / \mathrm{m}^{2}$ below the mean (Fig. 1, Table 1). While precipitation was above or near the mean in two of the following three years, forage production did not recover to average or above until 1958. A similar sequence was observed following the very dry year of 1964.

Long-term forage production at the CPER was significantly $(P \leq .05)$ related to annual precipitation, growing season precipitation, a linear combination of annual precipitation and annual temperature, and the ratio of annual precipitation to annual potential evapotranspiration (data not shown). Forage production was significantly $\left(F=30.83 ; \mathrm{df}=1,48 ; P<.001 ; r^{2}=0.39\right)$ related to annual precipitation by the equation:

$$
\begin{aligned}
& \text { Forage Production } \\
& \quad=13+0.172 \text { (Annual Precipitation). }
\end{aligned}
$$

The intercept was not significantly different from zero. The corresponding model using growing season precipitation where the growing season is defined from April through September was:

Forage Production

$$
=17+0.210 \text { (Growing Season Precipitation). }
$$

This model was also significant $(F=29.52$; df $=1,39$; 


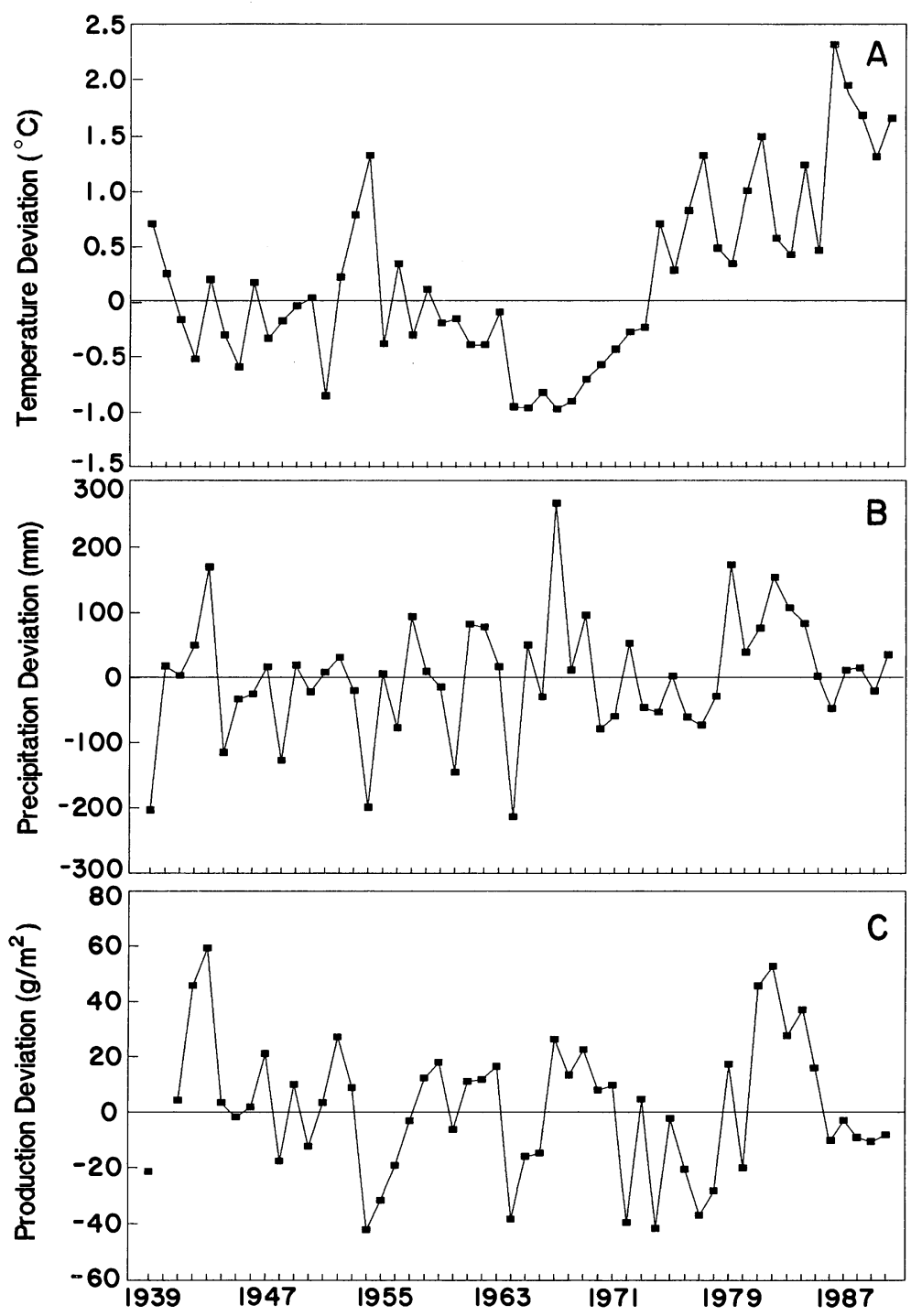

FIG. 1. Deviations of annual values from the long-term average for the period 1939-1990 for temperature (A), precipitation (B), and forage production, measured as live and attached-dead air-dry biomass at the end of the growing season for grasses, sedges, and forbs (C) for the Central Plains Experimental Range in north-central Colorado.

$\left.P<.001 ; r^{2}=0.43\right)$. The intercept again was not significantly different from zero.

Precipitation events are very likely not equivalent in their effects on ecosystem processes such as ANPP (Sala and Lauenroth 1982). Most past analyses have focused on the timing of precipitation using seasonal, water year, or monthly precipitation as independent variables (e.g., Smoliak 1986). We tested the idea that dividing growing season precipitation into events of different sizes would provide a more powerful explanation of the variability in production than could be obtained with all events lumped. The resulting model was:

Forage Production

$$
\begin{aligned}
= & 13.4+0.26\left(\mathrm{PPT}_{30}\right)+0.13\left(\mathrm{PPT}_{15}\right) \\
& +0.19\left(\mathrm{PPT}_{5}\right)+0.05\left(\mathrm{PPT}_{>30}\right)
\end{aligned}
$$

in which $\mathrm{PPT}_{30}$ was the amount of growing season precipitation that was received in events between 15 and $30 \mathrm{~mm}, \mathrm{PPT}_{15}$ events between 5 and $15 \mathrm{~mm}, \mathrm{PPT}_{5}$ events $<5 \mathrm{~mm}$, and $\mathrm{PPT}_{>30}$ all events $>30 \mathrm{~mm}$ (Table 1). This model was significant $(F=7.72 ; \mathrm{df}=4,37 ; P$ $\left.<.001 ; r^{2}=0.45\right)$, even though $\mathrm{PPT}_{30}$ was overwhelmingly the most important explanatory variable. A model with just $\mathrm{PPT}_{30}$ had an $r^{2}$ of 0.33 compared to the value of the full model of 0.45 .

\section{DisCussion}

The relationship between precipitation and forage production explained between 39 and $45 \%$ of the variability in production over the $52 \mathrm{yr}$ of observation. In many cases the deviations from the relationships were as interesting as the instances of good fit. For example, the dry years of 1954 and 1964 were followed by years 
of low forage production despite the fact that in both cases precipitation following the dry year was normal or above (Table 1). Such a lag in the recovery of forage production following a drought is likely the result of an interaction among population, community, and ecosystem processes (Webb et al. 1978). The structure of the vegetation, as reflected in abundance of lifeforms and species and in the density of seeds and tillers, provides a constraint within which normal fluctuations in precipitation cause bounded fluctuations in production. Drought conditions can result in plant or tiller mortality thus decreasing the capability of the current vegetation to respond to high resource availability. The data for 1954 and 1964 suggest a several-year lag in recovery. An extreme example of this phenomenon was documented for the major drought that occurred in the 1930s (Weaver and Albertson 1944).

Semiarid regions are widely thought of as especially variable in environmental conditions and biological responses (Noy-Meir 1973, Bailey 1979), and the shortgrass steppe is no exception (Coupland 1958, Wiens 1974). Fluctuation in precipitation is the principal cause of variability in grassland environments (Coupland 1958, Wiens 1974). Over the $52 \mathrm{yr}$ of observation at the CPER, precipitation ranged from nearly $70 \%$ below the long-term mean to $80 \%$ above it (Fig. 1). Observations included 3 yr of severe drought $(<50 \%$ of the mean) and three very wet years $(>150 \%$ of the mean). To a large extent the very wet and dry years occurred as isolated instances. As an example of the extremes in this semiarid environment, the driest year in the record $(1964 ; 104 \mathrm{~mm})$ was followed $3 \mathrm{yr}$ later by the wettest year in the record $(1967 ; 588 \mathrm{~mm})$.

The ideas of vegetation structure constraint on ANPP and time lags to recovery suggest that ANPP should be less variable than annual precipitation. However, forage production not only reflected but amplified the variability in precipitation (Table 1). Le Houérou et al. (1988) evaluated 77 data sets with 895 pairs of production and rainfall and reported a mean difference in variability of production over precipitation of $44 \%$. The reason for the greater variability of annual forage production than annual precipitation is likely related to the intraseasonal variability in water availability that occurs for a particular amount of annual precipitation. Wet years within which the increased precipitation is synchronous with the long-term pattern of precipitation are likely to be more productive than years that are wet because of very early and very late precipitation. Sala and Lauenroth (1982) speculated that small precipitation events should have a larger per unit effect on ecosystem dynamics than large events because of their potential to activate processes related to mineral nutrient supply. The most productive years should be those in which small precipitation events that stimulate mineral nutrient availability are followed by large events that stimulate plant production processes.
Arid and semiarid regions receive precipitation only $10-50 \mathrm{~d} / \mathrm{yr}$ and only 5-6 of these events are sufficiently large to affect biotic processes (Noy-Meir 1973). The CPER receives an average of 32 precipitation events during the May through August growing season, most of which are small (Sala and Lauenroth 1982). Over the $52 \mathrm{yr}$ of data collection, $17 \%$ of growing season precipitation was received in events $<5 \mathrm{~mm}, 36 \%$ in events between 5 and $15 \mathrm{~mm}, 30 \%$ between 15 and 30 $\mathrm{mm}$, and $17 \%$ in events $>30 \mathrm{~mm}$. According to our analysis, events in the range of $15-30 \mathrm{~mm}$ accounted for a larger fraction of the variability in primary production than other sizes (Eq. 4). We suggest that this is the combined effect of accounting for a large portion of the variability in precipitation as well as wetting the soil layers that are most effective in promoting production. Water from events in the $15-30 \mathrm{~mm}$ and larger size classes penetrate deeper into the soil than the more frequent events of $<15 \mathrm{~mm}$. Water from lower layers is lost only via transpiration since there is no deep percolation in this site, and evaporation only affects upper soil layers (Sala et al. 1992).

The concepts of a constraint on primary production by vegetation structure and time lags in responding to favorable conditions suggest an explanation for the difference in slope between the long-term model developed here and a regional model developed by Sala et al. (1988). Their analysis of the relationship between ANPP and annual precipitation for the Central Grasslands of the U.S. has a much steeper slope than the long-term relationship developed for the CPER (Fig. 2). At the maximum value of precipitation observed for the CPER, the prediction of the regional model was was significantly $(P<.05)$ higher than the estimate of the long-term model $\left(300\right.$ vs. $\left.130 \mathrm{~g} / \mathrm{m}^{2}\right)$. The magnitude if this difference decreased as annual precipitation approached the mean (Fig. 2). The Sala et al. (1988) regional model utilizes the ANPP of an ecosystem with a different vegetation structure at each value of precipitation. By contrast, the long-term model relates annual precipitation and ANPP for the same vegetation structure through time. If we assume the vegetation at a site is adapted to conditions in the neighborhood of modal water availability, we should expect that life-form and species composition constraints will limit responses to both very wet and dry conditions. Further, changes in vegetation structure can be slow and are mediated by changes in processes that range from expansion of the biomass or numbers of individuals of extant species to migration of new species (Tilman 1988, Coffin and Lauenroth 1990). These vegetation structure constraints on ANPP explain why, under dry conditions, the regional model underestimates ANPP and under wet conditions, overestimates ANPP.

The differences between regional and temporal models point out a weakness of exchanging space for time. Regional models predict the response of a set of dif- 


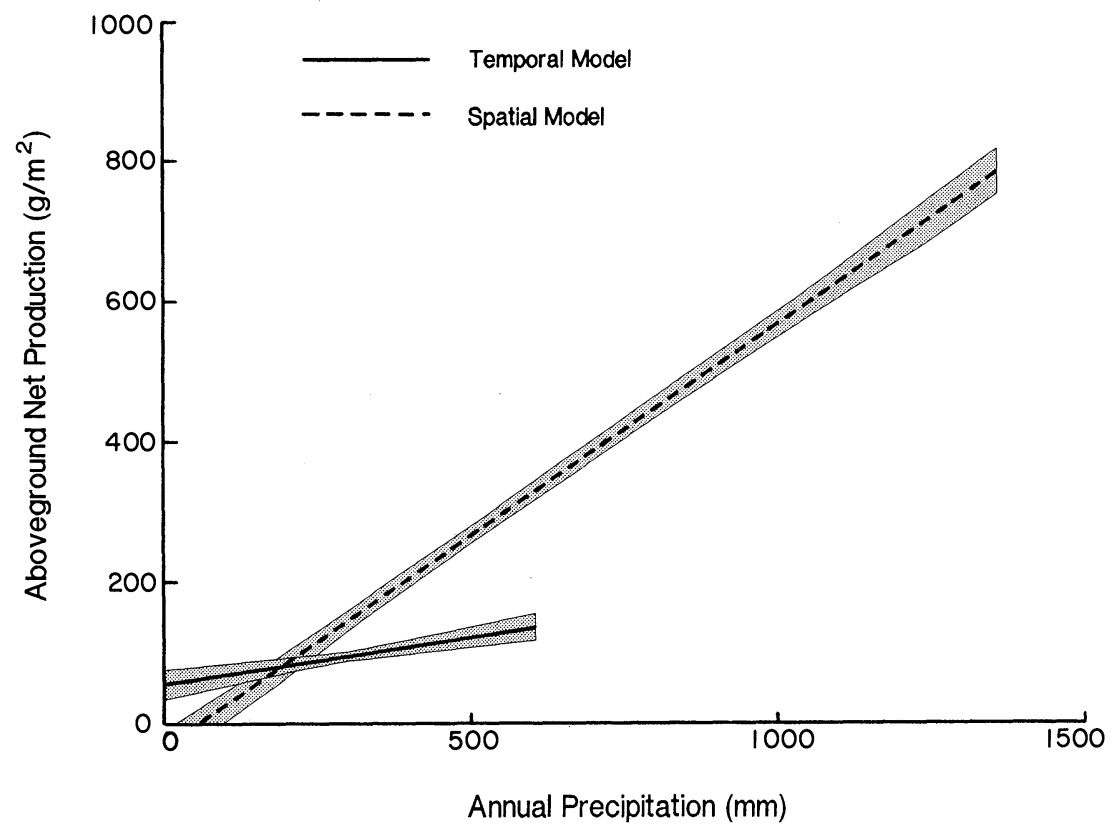

Fig. 2. Relationships between aboveground net primary production $\left(\mathrm{g} / \mathrm{m}^{2}\right)$ and annual precipitation (mm) for a regional model (Sala et al. 1988) for the Central Grassland Region of the U.S. and for the long-term model from this work for the Central Plains Experimental Range. Shaded areas represent 95\% confidence intervals. Regional model ANPP $=-34+$ 0.60(Ann. Precipitation). Long-term model ANPP $=56+0.13$ (Ann. Precipitation).

ferent ecosystems to spatial patterns in annual precipitation while temporal models predict responses of a single ecosystem to a time series of precipitation. Predictions of the effects of climate change on ANPP, based upon regional models, may contain important sources of previously unrecognized error. A better understanding of the characteristic response times of different ecosystems to changes in climate will be required if we are to make such predictions.

\section{ACKNOWLEDGMENTS}

The CPER is administered by the USDA Agricultural Research Service (ARS) and is a National Science Foundation funded Long Term Ecological Research site. We are grateful to the Great Plains Systems Research Unit, Agricultural Research Service for providing the long-term forage production data. We particularly acknowledge Marvin Shoop for his help with the data. Support for this work was provided by grants from the National Science Foundation (BSR 86-12105 and BSR 90-11659), the Colorado Agricultural Experiment State (1-50661), CONICET (INT 151/87), and Fundación Antorchas from Argentina.

\section{Literature Cited}

Bailey, H. P. 1979. Semiarid climates: their definition and distribution. Pages 73-97 in A. E. Hall, G. H. Cannell, and H. W. Lawton, editors. Agriculture in semiarid environments. Ecological Studies Analysis and Synthesis 34.

Coffin, D. P., and W. K. Lauenroth. 1990. A gap dynamics simulation model of succession in a semiarid grassland. Ecological Modelling 49:229-266.

Coupland, R. T. 1958. The effects of fluctuations in weather upon the grasslands of the Great Plains. Botanical Review 24:274-317.
Draper, N. R., and H. Smith. 1966. Applied regression analysis. John Wiley \& Sons, New York, New York, USA.

Great Plains Flora Association. 1986. Flora of the Great Plains. University Press of Kansas, Lawrence, Kansas, USA.

Kittel, T. G. F. 1990. Climate variability in the shortgrass steppe. Pages 67-75 in D. Greenland and L. W. Swift, editors. Climate variability and ecosystem response. United States Department of Agriculture Forest Service General Technical Report SE-65.

Lauenroth, W. K. 1979. Grassland primary production: North American grasslands in perspective. Pages 3-24 in N. R. French, editor. Perspectives in grassland ecology. Ecological Studies Analysis and Synthesis 32.

Lauenroth, W. K., H. W. Hunt, D. M. Swift, and J. S. Singh. 1986. Estimating aboveground net primary production in grasslands: a simulation approach. Ecological Modelling 33: 297-314.

Lauenroth, W. K., and D. G. Milchunas. 1991. Shortgrass steppe. Pages 183-226 in R. T. Coupland, editor. Natural grasslands: introduction and western hemisphere. Volume 8A. Ecosystems of the world. Elsevier, Amsterdam, The Netherlands.

Le Houérou, H. N. 1984. Rain use efficiency: a unifying concept in aridland ecology. Journal of Arid Environments 7:212-247.

Le Houérou, H. N., R. L. Bingham, and W. Skerbek. 1988. Relationship between the variability of primary production and the variability of annual precipitation in world arid lands. Journal of Arid Environments 15:1-18.

Milchunas, D. G., W. K. Lauenroth, P. L. Chapman, and M. K. Kazempour. 1989. Effects of grazing, topography, and precipitation on the structure of a semiarid grassland. Vegetatio 80:1 1-23.

Noy-Meir, I. 1973. Desert ecosystems: environment and producers. Annual Review of Ecology and Systematics 4: 25-51.

Rutherford, M. C. 1980. Annual plant production-precip- 
itation relations in arid and semiarid regions. South African Journal of Science 76:53-56.

Sala, O. E., and W. K. Lauenroth. 1982. Small rainfall events: an ecological role in semiarid regions. Oecologia (Berlin) 53:301-304.

Sala, O. E., W. K. Lauenroth, and W. J. Parton. 1992. Longterm soil water dynamics in the shortgrass steppe. Ecology 73:1175-1181.

Sala, O. E., W. J. Parton, L. A. Joyce, and W. K. Lauenroth 1988. Primary production of the central grassland region of the United States. Ecology 69:40-45.

Smoliak, S. 1986. Influence of climatic conditions on pro duction of Stipa-Bouteloua over a 50-year period. Journal of Range Management 39:100-103.
Tilman, D. 1988. Plant strategies and the dynamics and structure of plant communities. Princeton University Press, Princeton, New Jersey, USA.

Weaver, J. E., and F. W. Albertson. 1944. Nature and degree of recovery of grassland from the great drought of 1933. Ecological Monographs 14:393-479.

Webb, W., S. Szarek, W. K. Lauenroth, and R. Kinerson. 1978. Primary productivity and water use in native forest, grassland, and desert ecosystems. Ecology 59:1239-1247.

Wiens, J. A. 1974. Climatic instability and the "ecological saturation" of bird communities in North American grasslands. Condor 76:385-400. 